\title{
Hubungan Antara Beban Kerja dan Tingkat Pemahaman Perawat Mengenai Jangka Waktu Pengembalian Dokumen Rekam Medis Dengan Keterlambatan Pengembalian Dokumen Rekam Medis
}

\author{
${ }^{1}$ Teguh Achmalona*, ${ }^{2}$ Muhammad Amrullah, ${ }^{3}$ Suswinda Yuli Sutomo \\ 1,2,3 Universitas Qamarul Huda Badaruddin \\ *Email : aam.dais.ad@gmail.com
}

Kata kunci :
Beban Kerja,
Pemahaman
Perawat,
Rekam Medis


Keywords :
Workload,
Nurse
Understanding,
Medical
Records

Info Artikel :

Tanggal dikirim :

2 Maret 2021

Tanggal direvisi : 24 Maret 2021

Tanggal diterima : 19 April 2021

\section{DOI Artikel:}

10.33862/citradel ima.v5i1.213

Halaman: 11-17

\begin{abstract}
Abstrak
Dokumen rekam medis merupakan sumber penyediaan informasi medis pasien. Penatalaksanaan Rekam Medis yang baik, apabila dokumen tersebut akurat, lengkap, valid dan tepat waktu pengembalian. Tujuan penelitian ini untuk mencari hubungan antara beban kerja dan tingkat pemahaman perawat mengenai jangka waktu pengembalian dokumen rekam medis dengan keterlambatan pengembalian dokumen rekam medis di Rumah Sakit Islam Yatofa. Metode penelitian yang digunakan adalah deskriptif kuantitatif dengan pendekatan cross sectional. Proses pengambilan sampel dengan teknik total sampling yang berjumlah 65 orang. Teknik pengumpulan data menggunakan lembar kuesioner. Data kemudian dianalisis menggunakan uji statistik chi square. Hasil uji statistik variabel beban kerja diperoleh $p$ value $=0,000$ lebih kecil dari $\alpha=0,05$ menunjukkan bahwa ada hubungan bermakna antara beban kerja dengan keterlambatan pengembalian dokumen rekam medis. Sedangkan untuk variabel tingkat pemahaman diperoleh $p$ value $=0,005$ lebih kecil dari $\alpha=0,05$ menunjukkan ada hubungan antara tingkat pemahaman dengan keterlambatan pengembalian dokumen rekam medis. Keterlambatan pengembalian dokumen rekam medis disebabkan beban kerja perawat yang tinggi dan tingkat pemahaman perawat mengenai jangka waktu pengembalian dokumen rekam medis yang masih kurang. Hal tersebut harus diperhatikan guna menunjang terselenggaranya upaya peningkatan penatalaksanaan rekam medis yang baik dan dapat dipertanggung jawabkan oleh pihak terkait.
\end{abstract}

\section{Relationship Between Workload And Nurse's Level Of Understanding Regarding The Period Of Returning Medical Record Documents With Delays In Returning Medical Records Documents}

\section{Abstract}

Medical record documents are a source of providing patient medical information. Good medical record management, if the documents are accurate, complete, valid and on time for return. The purpose of this study was to find the relationship between workload and the level of understanding of nurses regarding the period of returning medical record documents with the delay in returning medical record documents at the Yatofa Islamic Hospital. The research method used is descriptive quantitative with cross sectional approach. The sampling process used total sampling technique, amounting to 65 people. The data collection technique used a questionnaire sheet. The data were analyzed using the chi square statistical test. The result of statistical test of workload variable obtained $\mathrm{p}$ value $=0.000$ which is smaller than $\alpha=0.05$, indicating that there is a significant relationship between workload and delay in returning medical record documents. Whereas for the level of understanding variable, it was obtained that $\mathrm{p}$ value $=0.005$ was smaller than $\alpha=0.05$, indicating that there was a relationship between the level of understanding and the delay in returning medical record documents. The delay in returning medical record documents is due to the high workload of nurses and the level of understanding of nurses regarding the period of returning medical record documents which is still lacking. This must be considered in order to support the implementation of efforts to improve the management of medical records that are good and can be held accountable by related parties. 


\section{PENDAHULUAN}

Berdasarkan peraturan yang tertuang dalam PERMENKES No. 269/MENKES/PER/II/2008, bahwa setiap sarana pelayanan kesehatan dituntut untuk memberikan pelayanan yang maksimal. Dengan demikian maka rumah sakit perlu ditunjang oleh rekam medis dan informasi kesehatan yang baik dan benar, karena rekam medis yang baik menjadi indikator pelayanan medis yang diberikan oleh rumah sakit juga baik. Organisasi penyelenggara rekam medis memiliki lingkup kerjasama antar satuan kerja yang sangat luas, dimulai dari pimpinan rumah sakit, dokter, keperawatan, sampai dengan tenaga kesehatan lainnya. Proses tersebut mulai pada saat diterimanya pasien di rumah sakit, kegiatan pencatatan data medis pasien selama pasien itu mendapatkan pelayanan medis rumah sakit dan dilanjutkan dengan pelayanan dokumen Rekam Medis yang meliputi penyelenggaraan, penyimpanan serta proses pengembalian kembali.

Penatalaksanaan Rekam Medis yang baik, akan menunjang terselenggaranya upaya peningkatan derajat kesehatan masyarakat indonesia untuk menghasilkan rekam medis yang baik dan dapat dipertanggung jawabkan. Rekam Medis memegang peranan penting dalam suatu penyedian informasi pasien, karena rekam medis adalah merupakan suatu berkas yang menjadi sumber dalam penyediaan informasi medis yang menggambarkan seluruh aspek pengelolahan rumah sakit dan aspek pelayanan yang diberikan terhadap pasien (Depkes RI, 2016).

Rekam medik yang lengkap adalah rekam medik yang telah diisi lengkap oleh dokter dalam waktu kurang dari 24 jam setelah selesai pelayanan baik rawat jalan atau setelah pasien rawat inap diputuskan untuk pulang. Proses pengembalian dokumen rekam medis dinyatakan terlambat apabila melebihi batas waktu pengembalian yaitu maksimal 2x24 jam setelah pasien keluar dari rumah sakit. Keterlambatan tersebut akan menghambat pelaksanaan tugas bagian assembling rekam medis yang akan berdampak pada terhambatnya proses pelayanan pasien, terutama pasien yang akan melakukan kontrol ulang setelah dirawat di poliklinik Rumah Sakit tersebut. Hal tersebut akan menghambat proses pendaftaran pasien rawat jalan (Puput, 2019).

Penelitian yang dilakukan oleh Abdul Roviq di RSAU dr Esnawan Antariksa Jakarta pada tahun 2019 tentang Determinan Penyebab Keterlambatan Penyediaan Dokumen Rekam Medis Rawat Jalan Poli Gigi dan Mulut menunjukkan hasil bahwa kompetensi petugas (pengetahuan, komunikasi dan ketrampilan) menyebabkan penyediaan dokumen rekam medis terlambat (Abdul, 2019).

Faktor lain juga dikaitkan dengan masalah tersebut, seperti beban kerja yang dimiliki perawat. Beban kerja yang tinggi membuat perawat hanya fokus dalam pelaksanaan asuhan keperawatan pada pasien tanpa memperhatikan proses pengembalian dan peletakan dokumen rekam medis milik pasien pulang yang sudah terisi lengkap. Hal tersebut membuat proses pengembalian dokumen rekam medis menjadi terlambat. Terlebih dengan tidak adanya petugas khusus bagian administrasi di ruang rawat inap, untuk mengantar setiap dokumen rekam medis ke bagian instalasi rekam medis membuat proses pengembalian dokumen rekam medis melebihi standar pengumpulan yang telah ditetapkan (Maria, 2019).

Hasil studi pendahuluan yang dilakukan oleh peneliti di RSI Yatofa pada tanggal 16 November melalui data sekunder dan wawancara dengan staf rekam medis maupun staf keperawatan menunjukkan bahwa rata-rata pengembalian dokumen rekam medis rawat inap dari ruang rawat inap ke bagian rekam medis di tahun 2020 adalah lebih dari empat hari. Hal ini jauh dari standar yang diharapkan yaitu kurang dari 2 × 24 jam.

Observasi awal juga dilakukan oleh peneliti dengan mengamati alur rekam medis rawat inap saat pasien pulang. Pada observasi awal tersebut, hampir di seluruh ruangan perawat di ruang rawat inap ditemukan tumpukan dokumen rekam medis pasien pulang. Saat wawancara dengan perawat diketahui bahwa rekam medis tersebut bukan hanya milik pasien yang baru diperbolehkan pulang, tetapi juga milik pasien yang sudah pulang lebih dari empat hari, menunggu tumpukan dokumen baru kemudian di antar.

Keterlambatan dalam pengembalian dokumen rekam medis akan berdampak pada terhambatnya proses pengolahan data, lambat dalam pengajuan klaim asuransi serta terhambatnya proses pendistribusian rekam medis yang akan membuat penyediaan dokumen rekam medis membutuhkan waktu yang lebih lama. Hal tersebut bisa mempengaruhi mutu pelayanan Rumah Sakit dan bisa mempengaruhi kepuasan pasien terhadap kualitas pelayanaan yang diberikan Rumah sakit tersebut (Melinda, 2016).

Berdasarkan permasalahan tersebut diatas penulis tertarik melakukan penelitian dengan judul "Hubungan Antara Beban Kerja dan Tingkat Pemahaman Perawat Mengenai Jangka Waktu Pengembalian Dokumen Rekam Medis Dengan 
Keterlambatan Pengembalian Dokumen Rekam Medis di Rumah Sakit Islam Yatofa"

\section{METODE}

Jenis penelitian ini adalah penelitian deskriptif kuantitatif. Suatu penelitian yang dilakukan dengan tujuan utama untuk memberikan gambaran atau deskripsi tentang suatu keadaan secara objektif, dengan pendekatan cross sectional (Dahlan, 2017).

Subyek yang digunakan dalam penelitian ini adalah semua perawat yang bertugas di instalasi rawat inap RSI Yatofa yang terlibat dalam proses pelaksanan asuhan keperawatan yang berjumlah 65 orang. Proses pengambilan sampel dilakukan dengan menggunakan teknik total sampling.

Tehnik pengumpulan data dalam penelitian ini menggunakan kuesioner hasil pengembangan peneliti. Kuesioner tersebut terdiri dari 1 kuesioner yang berisi 15 pertanyaan untuk beban kerja perawat dan 1 kuesioner yang berisi 15 pertanyaan untuk tingkat pemahaman perawat serta 1 lembar observasi yang digunakan untuk menilai ketepatan waktu pengumpulan berkas rekam medis secara langsung pada subjek penelitian dengan menghitung jumlah hari pengumpulan dokumen dari instalasi rawat inap ke instalasi rekam medis. Kuesioner yang digunakan telah melalui uji validitas dan reabilitas. Hasil uji validitas untuk masingmasing kuesioner menunjukkan hasil $r$ hiung $>\mathrm{r}$ tabel berdasarkan uji signifikan 0.05, artinya item-item pertanyaan tersebut valid. Untuk uji reabilitas dengan menggunakan rumus Alpha Cronbach diperoleh hasil 0.766 untuk variabel beban kerja dan 0.784 untuk variabel tingkat pemahaman perawat. Dari hasil tersebut dapat disimpulkan bahwa semua item pertanyaan untuk masing-masing variabel dinyatakan reliabel. Data yang diperoleh dari hasil penelitian tersebut selanjutnya diolah dengan menggunakan uji $c$-square.

\section{HASIL DAN PEMBAHASAN}

\section{Hasil}

Distribusi karakteristik responden

Tabel 1. Distribusi karakteristik responden berdasarkan umur.

\begin{tabular}{lccc}
\hline No & Umur & Frekuensi & Persentase \\
\hline 1. & $20-30$ & 38 & 58,5 \\
2. & $31-40$ & 27 & 41,5 \\
\hline Total & & 65 & 100 \\
\hline
\end{tabular}

Berdasarkan tabel diatas dari 65 responden terdapat 38 responden $(58,5 \%)$ berada pada kelompok umur 22-27 tahun dan 27 responden $(41,5 \%)$ berada pada kelompok umur 28-33 tahun.

Tabel 2. Distribusi karakteristik responden berdasarkan, jenis kelamin.

\begin{tabular}{lccc}
\hline No & Jenis kelamin & Frekuensi & Persentase \\
\hline 1. & Laki & 25 & 38,5 \\
2. & Perempuan & 40 & 61,5 \\
\hline \multicolumn{2}{l}{ Total } & 65 & 100 \\
\hline
\end{tabular}

Berdasarkan tabel diatas dari 65 responden terdapat 40 responden $(61,5 \%)$ memiliki jenis kelamin perempuan dan 25 responden $(38,5 \%)$ memiliki jenis kelamin laki-laki.

Tabel 3. Distribusi karakteristik responden berdasarkan pendidikan.

\begin{tabular}{lccc} 
No & Pendidikan & Frekuensi & Persentase \\
\hline 1. & D3 & 30 & 46,2 \\
2. Ners & 35 & 53,8 \\
\hline \multicolumn{2}{l}{ Total } & 65 & 100 \\
\hline
\end{tabular}

Berdasarkan tabel diatas dari 65 responden terdapat 35 responden $(53,8 \%)$ memiliki pendidikan Ners dan 30 responden $(46,2 \%)$ memiliki pendidikan D3.

Tabel 4. Distribusi karakteristik responden berdasarkan masa kerja.

\begin{tabular}{lccc}
\hline No & Masa kerja & Frekuensi & Persentase \\
\hline 1. & $<10$ & 42 & 64,6 \\
$2 . \quad>10$ & 23 & 35,4 \\
\hline Total & 65 & 100 \\
\hline
\end{tabular}

Berdasarkan tabel diatas dari 65 responden terdapat 42 responden $(64,6 \%)$ memiliki masa kerja $<10$ tahun dan 23 responden $(35,4 \%)$ memiliki pendidikan masa kerja $>10$ tahun.

http://jurnalilmiah.stikescitradelima.ac.id/index.php/JI Vol. 5 No.1 Juli 2021 
Distribusi karakteristik variabel

Tabel 2. Distribusi karakteristik variabel berdasarkan beban kerja perawat

\begin{tabular}{lccc}
\hline No & Beban Kerja & Frekuensi & Persentase \\
\hline 1. & Tinggi & 24 & 36,9 \\
2. & Sedang & 16 & 24,6 \\
3. & Rendah & 25 & 38,4
\end{tabular}

$\begin{array}{lll}\text { Total } & 65 & 100\end{array}$

Berdasarkan tabel diatas dari 65 responden terdapat 24 responden $(36,9 \%)$ memiliki beban kerja tinggi, 16 responden $(24,6)$ memiliki beban kerja sedang dan 25 responden $(38,5 \%)$ memiliki beban kerja rendah.

Tabel 3. Distribusi karakteristik variabel berdasarkan tingkat pemahaman perawat.

\begin{tabular}{llcc} 
No & Pemahaman & Frekuensi & Persentase \\
\hline 1. & Tinggi & 18 & 27,6 \\
2. & Sedang & 27 & 41,5 \\
3. & Rendah & 20 & 30,7 \\
Total & & 65 & 100 \\
\hline
\end{tabular}

Berdasarkan tabel diatas dari 65 responden terdapat 18 responden $(27,6 \%)$ memiliki pemahaman tinggi, 27 responden $(41,5 \%)$ memiliki sedang dan 20 responden $(30,7 \%)$ memiliki pemahaman rendah.

Tabel 4. Distribusi karakteristik variabel berdasarkan tingkat pengembalian dokumen rekam medis.

\begin{tabular}{llcc}
\hline No & Ketepatan & Frekuensi & Persentase \\
\hline 1. & Tepat & 18 & 27,7 \\
& & & \\
2. & Terlambat & 47 & 72,3 \\
& & 65 & 100 \\
\hline
\end{tabular}

Berdasarkan tabel diatas dari 65 dokumen rekam medis terdapat 47 dokumen $(72,3 \%)$ terlambat dalam pengumpulan dan 18 dokumen rekam medis $(27,7 \%)$ terlambat dalam pengumpulan.

Tabel 5. Tabulasi Silang hubungan beban kerja dengan keterlambatan pengembalian dokumen rekam medis

\begin{tabular}{|c|c|c|c|c|c|c|c|}
\hline Beban & & Ket & batan & & & & $\mathrm{P}-$ \\
\hline kerja & & & & & & lah & value \\
\hline & & pat & Ter & nbat & & & \\
\hline & $\mathrm{N}$ & $\%$ & $\mathrm{n}$ & $\%$ & $\mathrm{~N}$ & $\%$ & \\
\hline Tinggi & 0 & 0 & 24 & 36,9 & 24 & 36,9 & 0,000 \\
\hline Sedang & 0 & 0 & 16 & 24,6 & 16 & 24,6 & \\
\hline Rendah & 18 & 27,5 & 7 & 10,7 & 25 & 38,4 & \\
\hline Total & 18 & 27,5 & 47 & 72,5 & 65 & 100 & \\
\hline
\end{tabular}

Berdasarkan hasil analisis tabel di atas dapat disimpulkan bahwa responden dengan beban kerja tinggi mengalami keterlambatan dalam pengembalian dokumen rekam medis sebesar 36,9\%, responden dengan beban kerja sedang mengalami keterlambatan sebesar $24,6 \%$ dan responden dengan beban kerja rendah mengalami keterlambatan sebesar $10,7 \%$. Sedangkan untuk ketepatan pengembalian dokumen responden dengan beban kerja rendah sebesar $27,5 \%$. Hasil analisis didapatkan p-value $=$ 0.000 lebih kecil dari $\alpha=0,05$ menunjukkan bahwa ada hubungan bermakna antara beban kerja dengan keterlambatan pengembalian dokumen rekam medis.

Tabel 6.Tabulasi Silang hubungan antara tingkat pemahaman dengan keterlambatan pengembalian dokumen rekam medis

\begin{tabular}{|c|c|c|c|c|c|c|c|}
\hline \multirow{4}{*}{$\begin{array}{l}\text { Tingkat } \\
\text { Pemaha } \\
\text { man }\end{array}$} & \multirow{2}{*}{\multicolumn{4}{|c|}{ Ketepatan }} & \multirow{2}{*}{\multicolumn{2}{|c|}{ Jumlah }} & \multirow{4}{*}{$\begin{array}{c}\mathrm{P}- \\
\text { value }\end{array}$} \\
\hline & & & & & & & \\
\hline & \multicolumn{2}{|c|}{ Tepat } & \multicolumn{2}{|c|}{ Terlambat } & \multirow[b]{2}{*}{$\mathrm{N}$} & \multirow[b]{2}{*}{$\%$} & \\
\hline & $\mathrm{N}$ & $\%$ & $\mathrm{~N}$ & $\%$ & & & \\
\hline Tinggi & 18 & 27,5 & 0 & 0 & 18 & 27,5 & 0,005 \\
\hline Sedang & 0 & 0 & 27 & 41,5 & 27 & 41,5 & \\
\hline Rendah & 0 & 0 & 20 & 30,7 & 20 & 30,7 & \\
\hline Total & 18 & 27,5 & 47 & 72,5 & 65 & 100 & \\
\hline
\end{tabular}

http://jurnalilmiah.stikescitradelima.ac.id/index.php/JI Vol. 5 No.1 Juli 2021 
Berdasarkan hasil analisis tabel di atas dapat disimpulkan bahwa responden dengan tingkat pemahaman tinggi mengalami ketpatan dalam pengembalian dokumen rekam medis sebesar $27,5 \%$, responden dengan beban kerja sedang mengalami keterlambatan sebesar $41,5 \%$ dan responden dengan beban kerja rendah mengalami keterlambatan sebesar $30,7 \%$. Hasil analisis didapatkan p-value $=0.000$ lebih kecil dari $\alpha=0,05$ menunjukkan bahwa ada hubungan bermakna antara beban kerja dengan keterlambatan pengembalian dokumen rekam medis.

\section{Pembahasan}

\section{Hubungan Beban Kerja Perawat dengan Keterlambatan Pengembalian Dokumen Rekam Medis}

Hasil penelitian menunjukkan bahwa adanya hubungan yang signifikan antara beban kerja dengan keterlambatan pengembalian dokumen rekam medis dengan $\mathrm{p}$-value $=0,000$.

Dokumen rekam medis adalah berkas yang menjadi sumber penyediaan informasi medis pasien. Setelah dokumen rekam medis dinilai lengkap oleh kepala ruangan maka dokumen rekam medis rawat inap tersebut akan disetorkan ke bagian rekam medis. Penyetoran ini dilakukan oleh perawat jaga atau oleh petugas kurir untuk beberapa ruang rawat inap. Perawat jaga akan mengantar dokumen rekam medis ini jika sedang longgar yang artinya pekerjaan di pelayanan bisa ditinggalkan. Rekam medis yang sudah lengkap pada sore hari baru akan disetorkan keesokan harinya. Pengembalian dokumen rekam medis dengan tepat waktu sangat diperlukan untuk proses pengolahan data rekam medis. Keterlambatan pengumpulan berkas rekam medis akan menyebabkan proses pengolahan data akan menjadi terhambat yang akan berpengaruh terhadap proses pengambilan kebijakan, pengambilan keputusan serta penyampaian informasi kepada pasien (Ali, 2019).

Observasi di ruangan rawat inap juga dilakukan untuk mengetahui beban kerja perawat dalam pengisian rekam medis. Selama observasi, perawat terlihat sibuk memberikan pelayanan kepada pasien. Kepala ruangan lebih banyak mengurusi masalah dokumen, sedangkan pelayanan ditangani oleh perawat jaga. Untuk ruangan kelas VIP (very important person) rasio perawat dan pasien masih mencukupi. Tetapi untuk ruangan kelas I dan kelas III, terutama karena lebih sering penuh, sehingga beban kerja perawat cukup tinggi Kelas 3 memiliki kapasitas tempat tidur (TT) sejumlah 39 TT, dengan jumlah perawat 16 . Setiap shift jaga dijaga oleh
3-4 perawat, sehingga setiap perawat bertanggung jawab terhadap 10-13 pasien. Kesibukan ini sangat terlihat terutama di ruang kelas III, saat observasi selama 1 jam di ruang rawat inap kelas 3 pada pagi hari, tidak terlihat ada perawat yang menganggur. Satu orang perawat berkeliling dari satu pasien ke pasien lain untuk memeriksa TTV (tanda tanda vital), dua orang mengerjakan dokumentasi, dan kepala perawat mengorganisir dokumen rekam medis pasien yang sudah pulang dan melengkapinya (Profil RSI, 2020).

Temuan ini sejalan dengan penelitian yang dilakukan oleh Erlinda di Rumah sakit Vena Estetika bahwa ketidaklengkapan dan keterlambatan pengisian rekam medis disebabkan oleh tingginya beban dokter, perawat atau tenaga medis lainnya. Pasien yang banyak setiap harinya membuat kebanyakan tenaga kesehatan melewatkan untuk menuliskan nama dan membubuhkan paraf atau tandatangan di setiap formulir rekam medis bahkan sampai terlambat dalam proses pengembalian. Selain itu kurangnya pemahaman mengenai pentingnya rekam medis sebagai bukti otentik pelayanan kesehatan yang diberikan kepada pasien, juga berpengaruh terhadap masalah ini (Erlinda, 2016).

Hal tersebut jika dibiarkan terus-menerus, akan membuat pelayanan yang ada di rumah sakit tersebut akan terganggu sehingga berakibat pada kualitas pelayanan yang diberikan kepada para konsumen sebagai penerima jasa yang disediakan Rumah Sakit.

\section{Hubungan Pemahaman Perawat Mengenai Jangka Waktu Pengembalian Dokumen dengan Keterlambatan Pengembalian Dokumen Rekam Medis}

Hasil penelitian menunjukkan bahwa ada hubungan antara tingkat pemahaman perawat mengenai jangka waktu pengembalian dokumen rekam medis dengan keterlambatan pengembalian dokumen rekam medis rawat inap dengan $\mathrm{p}$-value $=0.005$. Kurangnya pemahaman mengenai hal tersebut tentunya bisa memberikan dampak yang negative terhadap pelayanan yang ada di rumah sakit.

Hal ini di lihat dari hasil pengisian kuisioner yang di berikan kepada perawat yang terlibat di dalam pengisan dokumen rekam medis dengan tingkat pemahaman yang masih kurang. Sebagian besar perawat tidak paham mengenai batas maksimal pengumpulan dokumen rekam medis tersebut. Dalam hal ini pihak rumah sakit perlu melakukan sosialisasi baik itu berupa SOP dan kebijakan terkait dengan upaya untuk mengatasi masalah tersebut dengan meningkatkan

http://jurnalilmiah.stikescitradelima.ac.id/index.php/JI Vol. 5 No.1 Juli 2021 
indikator peningkatan kualitas SDM baik itu secara formal maupun informal (Lihawa, 2015).

Penlitian ini sejalan dengan yang ditemukan oleh Purba di Rumah Sakit Estomihi Medan. Hasil penelitian tersebut menunjukkan faktor penyebab keterlambatan waktu pengembalian dokumen rekam medis rawat inap yaitu disebabkan oleh dokter yang terlambat mengisi kelengkapan berkas rekam medis, belum adanya petugas khusus pengembalian berkas rekam medis rawat inap, serta jarak Instalasi rawat inap ke Instalasi rekam medis yang cukup jauh mengakibatkan keterlambatan dalam proses pengembalian dokumen rekam medis (Purba, 2019).

Menurut pendapat peneliti, tingkat pemahaman perawat mempunyai hubungan yang erat dengan faktor social, budaya, ekonomi dan perilaku demografi seperti pendidikan, pekerjaan, lingkungan, pengalaman dan status kesehatan. Semakin tinggi tingkat pemahaman perawat maka akan semakin baik kualitas pelayan yang akan di berikan. Hal tersebut menjadi landasan untuk mengembangkan diri serta kemampuan memanfaatkan semua sarana yang ada di sekitar kita untuk kelancaraan tugas.

Pengembalian rekam medis yang tepat waktu dapat berpengaruh terhadap pengolahan data dan informasi yang dibutuhkan oleh rumah sakit. Adanya keterlambatan pengembalian berkas rekam medis akan menghambat kegiatan selanjutnya, yaitu kegiatan koding, indeks, serta kemungkinan menyebabkan hilang atau rusaknya berkas rekam medis. Apabila hal tersebut terjadi secara berkelanjutan maka akan menghambat penyampaian informasi kepada pemimpin rumah sakit untuk pengambilan keputusan. Hal tersebut juga menghambat proses keberlangsungan pembiayaan kesehatan klaim BPJS. Keterlambatan klaim BPJS dapat berdampak pada terganggunya keuangan rumah sakit yang akan berimbas pada keterlambatan penggajian karyawan dan terganggunya dana operasional rumah sakit (Septiani, 2016).

\section{SIMPULAN}

Berdasarkan hasil penelitian tersebut dapat disimpulkan bahwa :

1. Ada hubungan antara beban kerja dengan keterlambatan pengembalian dokumen rekam medis di Rumah Sakit Islam Yatofa.

2. Ada hubungan antara tingkat pemahaman perawat mengenai jangka waktu pengembalian dokumen rekam medis dengan keterlambatan pengembalian dokumen rekam medis di Rumah Sakit Islam Yatofa.

\section{DAFTAR PUSTAKA}

Abdul, R. (2019). Determinan Penyebab Keterlambatan Penyediaan Dokumen Rekam Medis Rawat Jalan Poli Gigi dan Mulut di RSAU dr. Esnawan Antariksa Jakarta. Jurnal Manajemen Dan Administrasi Rumah Sakit 4 (1)

Ali, H. (2019). Faktor-faktor yang mempengaruhi keterlambatan pengembalian berkas rekam medis rawat jalan di UPT Rumah Sakit Khusus Paru Medan. Jurnal Ilmiah Perekam dan Informasi Kesehatan Imelda, 5 (1), 108-113.

Dahlan MS. Statistik Untuk Kedokteran dan Kesehatan. Seri 1, ed 6.2017.

Depkes RI. (2016). Pedoman Penyelenggara Dan Prosedur Rekam Medis Rumah Sakit Di Indonesia. Revisi II. Jakarta

Erlinda, (2016). Analisis Faktor Keterlambatan Pemulangan Berkas Rekam Medis Dari Instalasi Rawat Inap Ke Unit Instalasi Rekam Medis Di Rumah Sakit Vena Estetica Medan.

Kepmenkes RI Nomor 129/Menkes/SK/II/2008, Tentang Standar Pelayanan Minimal Rumah Sakit Menteri Kesehatan Republik Indonesia.

Lihawa, C., Mansur, M., dan Wahyu, T. (2015). Faktorfaktor penyebab ketidaklengkapan pengisian rekam medis dokter di ruang rawat inap RSI Unisma Malang. Jurnal Kedokteran Brawijaya, 28(2), 119-123.

Maria, L. (2019). Analisa Pengembalian Dokumen Rekam Medis Pasien Rawat Jalan Pada Ruang Filling di RSUD Kanjuruhan Kabupaten Malang.

Meilinda, D. (2016). Tinjauan Ketepatan Waktu Pengembalian Rekam Medis Rawat Jalan di Rumah Sakit Jiwa DR. Soeharto Heerdjan.

Menteri Kesehatan Republik Indonesia. (2008). Peraturan Menteri Kesehatan Republik Indonesia nomor 269/MENKES/PER/III/2008 tentang rekam medis. Jakarta: Kementerian Kesehatan RI

Profil Laporan Tahunan Rumah Sakit Islam Yatofa Tahun 2020.

Puput, M. (2019). Faktor-Faktor Penghambat Pelayanan di Tempat Pendaftaran Pasien BPJS Rawat Jalan di Rumah Sakit Sari Mutiara, Lubuk Pakam Deli Serdang. Jurnal Ilmiah Perekam dan Informasi Kesehatan Imelda. 4 (2), 668-674.

Purba, E. (2019). Faktor Penyebab Keterlambatan Waktu Pengembalian Berkas Rekam Medis Rawat inap di RS Estomihi Medan Tahun 2019. Jurnal

http://jurnalilmiah.stikescitradelima.ac.id/index.php/JI Vol. 5 No.1 Juli 2021 
Ilmiah Perekam dan Informasi Kesehatan Imelda. 4 (2), 626-636.

Septiani, Resti, Nurdiah, Arief Tarmansyah Iman. (2016). Analisis Penyebab Unclaimed Berkas BPJS Rawat Inap di RSUD Dr. Soekardjo Tasikmalaya. Jurnal Manajemen Informasi Kesehatan Indonesia. 4 (2). 